\title{
BIOTRANSFORMATION STUDIES OF PREDNISONE USING HUMAN INTESTINAL BACTERIA; PART I: AEROBIC INCUBATION
}

Mohammed M. Al-Sanea, Atef A. Abdel-Hafez, Farghaly A. Omar and Adel F. Youssef

Department of Medicinal Chemistry, Faculty of Pharmacy, Assiut University, Assiut 71526, Egypt

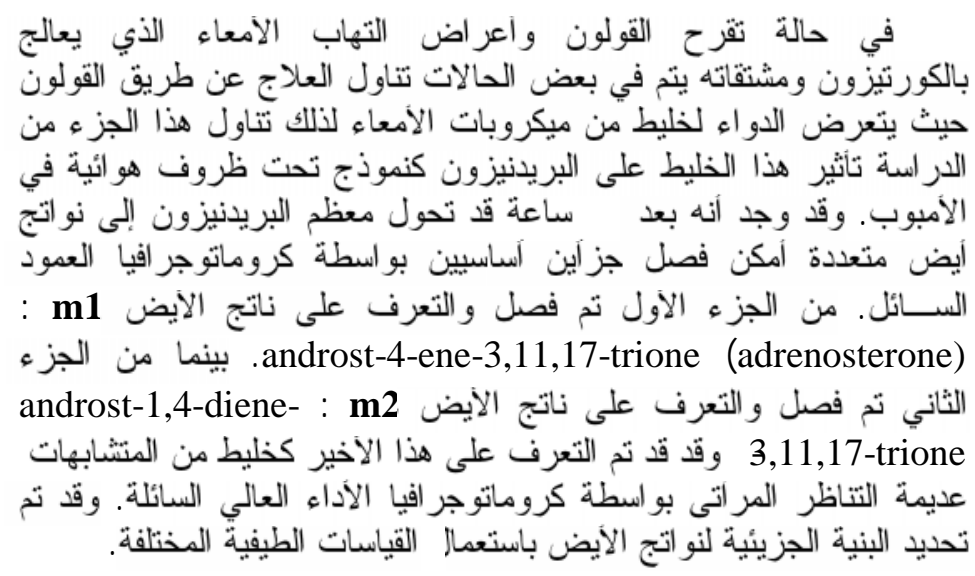

Several corticosteroids are commonly used for treatment of conditions associated with inflammatory disorders and as immune modulators. Specifically in cases of ulcerative colitis and the related inflammatory bowel syndromes, these therapeutic agents are administered rectally and are subjected to several intestinal micro floras. The present study aimed to investigate the effect of human intestinal bacterial (HIB) aerobic incubation on prednisone 1 as a model for corticosteroids. Within 96 hours, 1 was mostly transformed by HIB in vitro to various metabolites, which could be separated by column chromatography into two fractions. The first eluted fraction $A$ was found to contain the major metabolite adrenosterone, androst-4-ene-3,11,17-trione $\boldsymbol{m}_{1}$, whereas fraction $B$ contains metabolite $\boldsymbol{m}_{2}$, which was identified by chiral HPLC as a mixture of androst-1,4-diene-3,11,17-trione enantiomers. The structures of metabolites $\boldsymbol{m}_{\boldsymbol{1}}$ and $\boldsymbol{m}_{2}$ were identified and characterized by spectroscopic techniques, including $2 D-N M R$ and 
mass spectrometry. Time course of biotransformation of 1 by HIB was also studied.

\section{INTRODUCTION}

The biotransformation studies represent one of the valuable tools at every stage of the drug discovery, from library construction, lead optimization to the development stage. In the initial lead expansion phase, biotransformation reactions are used as a tool in medicinal chemistry, leading to substitutions that are also at positions difficult to access by synthetic approaches ${ }^{1}$. These derivatives help in refining the structure-activity relationship, that potentially leading to new ideas of compounds to be synthesized. Additionally, they can be favorably combined with synthetic work applied to related structures, thus multiplying the number of accessible compounds for screening.

Several glucocorticoids are used per rectal administration in the treatment and management of inflammatory bowel syndromes (IBS) such as ulcerative colitis and Crohn's diseases $^{2}$. Prednisone 1, in order to be effective, must be bioactivated to the corresponding 11-hydroxy analogue, prednisolone, by liver enzymes in the body. The latter is then converted to less active hydrophilic metabolites such as 6 6 -hydroxyprednisolone, $20 \alpha / \beta$-hydroxy-prednisolone and $16 \alpha$ hydroxyprednisolone, which are primarily excreted as glucuronide conjugates in the urine ${ }^{3}$.

Microbial transformation of prednisone 1 using Cunninghamella elegans afforded two metabolites, $17 \alpha, 21$-dihydroxypregn-1-ene-

3,11,20-trione $\mathbf{2}$ and $17 \alpha, 20 \mathrm{~S}, 21$ trihydroxypregn-1-ene-3,11-dione $\mathbf{3}$. Meanwhile the fermentation with Fusarium lini, Rhizopus stolonifer and Curvularia lunata afforded one metabolite, $17 \alpha, \quad 20 S, \quad 21$ trihydroxypregna-1,4-diene-3,11-

dione 4, which elicits more inhibitory activity against lipoxygenase enzyme than prednisone ${ }^{4}$.

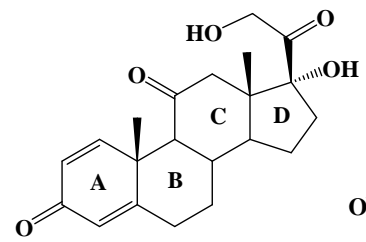

1<smiles>CC12C=CC(=O)CC1CCC1C2C(=O)CC2(C(O)CO)[C@@H](O)CC[C@H]12</smiles>

3

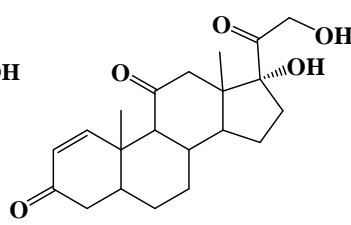

2<smiles>CC12C=CC(=O)C=C1CCC1C2C(=O)CC2(C)C1CC[C@@]2(O)C(O)CO</smiles>

4
Heretofore, the metabolic studies of 1 involving human intestinal flora have not been reported. Consequently, in the scope of the aforementioned therapeutic applications of corticosteroids, it is 
worthy to investigate the microbial biotransformation of corticosteroid using human intestinal flora. In the present study, we report the isolation and structural determination of two metabolites obtained after aerobic incubation of prednisone $\mathbf{1}$ with the fecal bacterial mixture from a human subject.

\section{EXPERIMENTAL}

Melting points were determined on an electrothermal melting point apparatus (Stuart Scientific Co.) in capillary tubes and were uncorrected. ${ }^{1} \mathrm{H}-$ and ${ }^{13} \mathrm{C}-\mathrm{NMR}$ spectra were recorded using either JEOL JNM ECA $500\left({ }^{1} \mathrm{H}, 500 \mathrm{MHz} ;{ }^{13} \mathrm{C}, 125\right.$ $\mathrm{MHz}$ ) spectrometer at the NMR Laboratory Center, Faculty of Science, Alexandrian University, Alexandria/ Egypt; or Varian JEOL JNM-EX $400\left({ }^{1} \mathrm{H}, 400 \mathrm{MHz} ;{ }^{13} \mathrm{C}, 100\right.$ $\mathrm{MHz}$ ) spectrophotometer, NMR Laboratory Center, Assiut University, Assiut/Egypt. Chemical shifts were given in $\delta(\mathrm{ppm})$ relative to TMS. ${ }^{1} \mathrm{H}-$ Heteronuclear Multiple Quantum Coherence (HMQC) experiments were performed with the usual pulse sequence; and data processing was obtained with standard Varian software. Electron impact (EI) mass spectra were recorded with a JEOL, JMS-600 spectrometer at an ionization voltage of $70 \mathrm{eV}$ (JEOL, Tokyo, Japan) at Central lab, Assiut University, and the Micro analytical center, Faculty of Science, Cairo University, Cairo/Egypt. Binder aerobic incubator was used for aerobic incubation.

Thin layer chromatography was carried out on pre-coated silica gel 60 $\mathrm{GF}_{254}$ plates $(0.25 \mathrm{~mm}$ thickness, Merck, Darmstadt, Germany) and the spots were detected under UV at 254 $\mathrm{nm}$. Column chromatography was carried out using silica gel $60(0.063$ $0.200 \mathrm{~mm}$ ) (E. Merck, Germany). The HPLC system consisted of a Knauer model 64, solvent delivery module (Knauer, Germany), Knauer variable wavelength UV detector, 20-1 sample loop, and a Shimadzu CR-6A chromatopac integrator (Shimadzu, Tokyo, Japan), and the retention time $\left(\mathrm{R}_{\mathrm{t}}\right)$ was recorded in minutes. The column used was Phenomenex LUNA C18 column $(150 \mathrm{~mm} \times 4.6$ $\mathrm{mm}$ i.d., $5 \mathrm{~m}$ ). The effluent was monitored at $240 \mathrm{~nm}$ at a flow rate of $1 \mathrm{ml} / \mathrm{min}$. Mobile phase consisting of acetonitrile/water (2:3). The chiral column used was Daicel Chiralcel OD-H column $(150 \mathrm{~mm}$ x $4.6 \mathrm{~mm}$ i.d., $5 \mathrm{~m}$ ). The effluent was monitored at $240 \mathrm{~nm}$ at a flow rate of $1 \mathrm{ml} / \mathrm{min}$. Mobile phase consisting of isopropanol $/ n$-hexane (1:50).

Prednisone 1 was extracted from Hostacortin ${ }^{\circledR}$ tablets according to the procedure described in USP XXII. Two hundred tablets, equivalent to about $1 \mathrm{~g}$ of prednisone were pulverized and extracted with $1 \mathrm{~L}$ of solvent hexane, with frequent agitation and slight warming, for 15 minutes. The supernatant liquid was decanted and discarded. The residue was then extracted with $400 \mathrm{ml}$ of chloroform for 15 minutes, and the 
mixture was filtered. Methanol (400 $\mathrm{ml}$ ) was added to the filtrate, mixed, and evaporated to dryness on a steam bath with the aid of a current of air. The residue was dried at $105^{\circ}$ for 30 minutes and used without further purification as working reference material ${ }^{5}$. All other chemicals and solvents were of analytical grade.

\section{Stock solutions and mixtures}

a) HIB suspension: Fresh fecal sample provided from healthy volunteer $\left(\begin{array}{ll}150 & \mathrm{~g}\end{array}\right)$ was homogenized at $37^{\circ} \mathrm{C}$ with 1500 $\mathrm{ml}$ potassium phosphate buffer $(50 \mathrm{mmol}, \mathrm{pH} 7.3)$ in a sterilized $2 \mathrm{~L}$ flask and the supernatant was decanted and used immediately.

b) Prednisone solution: One-gram prednisone was dissolved in 25 ml dioxane: methanol mixture (3:1).

c) Test suspension: Prepared by adding prednisone solution (25 $\mathrm{ml})$ to HIB suspension $(975 \mathrm{ml})$ to give a final concentration of 1 $\mathrm{mg} / \mathrm{ml}$ and then mixed well using magnetic stirrer.

d) Substrate control: An aliquot of prednisone solution was added to potassium phosphate buffer (50 mmol, $\mathrm{pH} 7.3$ ) to give a final dilution of $1 \mathrm{mg} / \mathrm{ml}$ and used as control solution.

e) HIB culture control: An aliquot of HIB suspension was used in the control experiments.

\section{Procedure}

The test suspension, the substrate control solution, and the HIB culture control were aerobically incubated at $37^{\circ} \mathrm{C}$ for 4 days. At $24 \mathrm{~h}$ intervals the reaction mixture was mixed using vortex mixer three times each for one minute and samples $(2 \mathrm{ml})$ were withdrawn from the solutions as well as suspensions and transferred to test tubes. Ethyl acetate $(2 \mathrm{ml})$ was added to each tube, and mixed by vortex three times each for one minute. Ethyl acetate extracts were applied on TLC plate then developed using n-hexane: ethyl acetate (3:1) and spots of metabolites were located under UV lamp. At the end of the incubation period, the test suspension was extracted with ethyl acetate $(500 \mathrm{ml} \mathrm{x}$ 4). The extract was dried over anhydrous sodium sulphate, filtered and the solvent was removed under reduced pressure. The residue was chromatographed over silica gel column $(25 \mathrm{~cm}$ length $\times 1.5 \mathrm{~cm}$ internal diameter) with hexane: ethyl acetate using gradient elution method starting with $100 \%$ hexane and ended to $70 \%$ hexane in ethyl acetate. Fraction A was collected and evaporated in vacuo, dried using vacuum desiccator to yield metabolite $\mathbf{m}_{1}(60 \mathrm{mg})$. Fraction B was collected and concentrated then dried using vacuum desiccator to yield metabolite $\mathbf{m}_{\mathbf{2}}$ (21 mg).

\section{Microbial biotransformation time course}

Five aliquots of $10 \mathrm{ml}$ each were pipetted from the stock solutions and suspensions $\mathrm{c}, \mathrm{d}$ and $\mathrm{e}$ and transferred into 5 test tubes then aerobically incubated at $37^{\circ} \mathrm{C}$ for 4 days.

At $0,24,48,72$ and $96 \mathrm{~h}$ time intervals ethyl acetate $(3 \mathrm{ml})$ was 
added to each tube and mixed gently by vortex for 1 minute. Aliquots of 3001 of ethyl acetate extract were transferred into $50 \mathrm{ml}$ volumetric flask and completed to the mark with mobile phase $\mathrm{CH}_{3} \mathrm{CN}$ : $\mathrm{H}_{2} \mathrm{O}$ (2:3) and analyzed by injection into HPLC using $\mathrm{CH}_{3} \mathrm{CN}: \mathrm{H}_{2} \mathrm{O}(2: 3)$ as mobile phase.

Androst-4-ene-3, 11, 17-trione $\left(m_{1}\right)^{6}$ : Colorless crystalline solid; m.p. 222-224; UV (MeOH) $\lambda_{\max } 240$ $\mathrm{nm} ; \mathrm{R}_{\mathrm{t}}=7.87 \min \left(\mathrm{CH}_{3} \mathrm{CN}: \mathrm{H}_{2} \mathrm{O}\right.$, 2:3); ${ }^{1} \mathrm{H}-\mathrm{NMR}\left(\mathrm{CDCl}_{3}, 500 \mathrm{MHz}\right)$, and ${ }^{13} \mathrm{C}$-NMR $\left(\mathrm{CDCl}_{3}, 125 \mathrm{MHz}\right)$ [Tables 1 and 2, respectively]. EI-MS $\mathrm{m} / \mathrm{z}$ (rel. int.) $300[\mathrm{M}]^{+}(39), 282(2)$, 256 (10), 228 (7), 122 (100); CAS $382-45-6$.

\section{Androsta-1,4-diene-3,11,17-trione}

$\left(\mathbf{m}_{2}\right)^{6}$ : Colorless crystalline solid; m.p. $197-198^{\circ} \mathrm{C}$; UV $(\mathrm{MeOH}) \lambda_{\max } 240$ $\mathrm{nm} ; \mathrm{R}_{\mathrm{t}}=7.1$ min. $\left(\mathrm{CH}_{3} \mathrm{CN}: \mathrm{H}_{2} \mathrm{O}, 2: 3\right)$; ${ }^{1} \mathrm{H}-\mathrm{NMR}\left(\mathrm{CDCl}_{3}, 400 \mathrm{MHz}\right)$, and ${ }^{13} \mathrm{C}-\mathrm{NMR}\left(\mathrm{CDCl}_{3}, 100 \mathrm{MHz}\right)$ [Tables 1 and 2, respectively]. EI-MS $m / z$ (rel. int.) $298.20[\mathrm{M}]^{+}$(100), 280 (7), 270 (37), 254 (37); CAS 7738-93-4.

\section{RESULTS AND DISCUSSION}

Prednisone 1 was extracted from marketed Hostacortin ${ }^{\circledR}$ tablets following the procedure described by USP XXII ${ }^{5}$. ${ }^{1} \mathrm{H}-\mathrm{NMR}$ and ${ }^{13} \mathrm{C}-\mathrm{NMR}$ spectral data were carried out and listed in Tables 1 and 2 guided by the available reported figures ${ }^{4}$. Matching the found spectral data of prednisone 1 with that of the metabolites might assist in the elucidation of the structures of the isolated products.

Aerobic incubation of $\mathbf{1}$ with HIB was carried out parallel with substrate control and HIB culture control experiments. Each run of the three experiments was monitored by TLC at $24 \mathrm{~h}$ time intervals. During the total period of incubation (96 h), control experiments did not show any new profile of developed spots other than that elicited in the test experiment at incubation zero time. This demonstrated the fitness of viable aerobic bacteria from human feces as the unique source of the developed spots for the span of the test experiments. At the end of incubation period the test experiments were processed and the ethyl acetate extract residue was chromatographed by silica gel column. Two fractions A and $\mathrm{B}$ were collected from the open silica column.

Fraction $\mathbf{A}\left(\mathrm{R}_{\mathrm{f}}=0.77\right)$ that eluted firstly was suitably purified to give a relatively high yield of the metabolite $\mathbf{m}_{1}$. Mass spectrum of $\mathbf{m}_{1}$ revealed the molecular ion peak at m/z $300\left[\mathrm{M}^{+}\right]$ demonstrating 58 mass units less than the parent compound $\mathbf{1}$, which most probably indicates cleavage of the $\alpha$ ketol group at $\mathrm{C}-17$. The ${ }^{1} \mathrm{H}-\mathrm{NMR}$ spectral data (Table 1), showed only one downfield olefinic proton signal at $\delta 5.67(1 \mathrm{H}, \mathrm{s}, \mathrm{H}-4)$ in addition to two pairs of multiplets integrated by two protons each; one pair at $\delta 1.62$, 2.05 , and second at 2.4 and $2.5 \mathrm{ppm}$, that was assigned to the ethylenic protons on $\mathrm{C}_{1}$ and $\mathrm{C}_{2}$ respectively. Furtherly, the observed absence of 
Table 1: ${ }^{1} \mathrm{H}-\mathrm{NMR}$ spectral data of prednisone ${ }^{6}$ and its aerobic HIB biotransformation products $\mathbf{m}_{\mathbf{1}}$ and $\mathbf{m}_{\mathbf{2}}$.

\begin{tabular}{|c|c|c|c|}
\hline $\begin{array}{c}\text { Proton } \\
\text { No }\end{array}$ & $\mathbf{1}^{\mathrm{a}}$ & $\mathbf{m}_{1}{ }^{b}$ & $\mathbf{m}_{2}{ }^{\mathrm{c}}$ \\
\hline H-1 & $7.55(1 \mathrm{H}, \mathrm{d}, J=10.7)$ & $1.62(1 \mathrm{H}, \mathrm{m}), 2.05(1 \mathrm{H}, \mathrm{m})$ & $7.59(1 \mathrm{H}, \mathrm{d}, J=10.28)$ \\
\hline H-2 & $6.06(1 \mathrm{H}, \mathrm{dd}, J=10.7,1.9)$ & $2.4(1 \mathrm{H}, \mathrm{m}), 2.5(1 \mathrm{H}, \mathrm{m})$ & $6.15(1 \mathrm{H}, \mathrm{dd}, J=10.28,1.9)$ \\
\hline H-4 & $5.97(1 \mathrm{H}, \mathrm{d}, J=1.9)$ & $5.67(1 \mathrm{H}, \mathrm{s})$ & $6.04(1 \mathrm{H}, \mathrm{d}, \mathrm{J}=1.9)$ \\
\hline H-6 & $1.9(2 \mathrm{H}, \mathrm{m})$ & $2.4(1 \mathrm{H}, \mathrm{m}), 2.2(1 \mathrm{H}, \mathrm{m})$ & $2.4(1 \mathrm{H}, \mathrm{m}), 2.2(1 \mathrm{H}, \mathrm{m})$ \\
\hline H-7 & $1.65(2 \mathrm{H}, \mathrm{m})$ & $2.1(1 \mathrm{H}, \mathrm{m}), 1.8(1 \mathrm{H}, \mathrm{m})$ & $2.1(1 \mathrm{H}, \mathrm{m}), 1.8(1 \mathrm{H}, \mathrm{m})$ \\
\hline H-8 & $1.9(1 \mathrm{H}, \mathrm{m})$ & $1.9(1 \mathrm{H}, \mathrm{m})$ & $1.9(1 \mathrm{H}, \mathrm{m})$ \\
\hline H-9 & $2.13(1 \mathrm{H}, \mathrm{m})$ & $2.5(1 \mathrm{H}, \mathrm{m})$ & $2.5(1 \mathrm{H}, \mathrm{m})$ \\
\hline H-12 & $\begin{array}{c}2.22(1 \mathrm{H}, \mathrm{m}) \\
\text { and } 2.31(1 \mathrm{H}, \mathrm{m})\end{array}$ & $2.4(1 \mathrm{H}, \mathrm{m}), 2.1(1 \mathrm{H}, \mathrm{m})$ & $2.4(1 \mathrm{H}, \mathrm{m}), 2.1(1 \mathrm{H}, \mathrm{m})$ \\
\hline H-14 & $1.9(1 \mathrm{H}, \mathrm{m})$ & $1.6(1 \mathrm{H}, \mathrm{m})$ & $1.6(1 \mathrm{H}, \mathrm{m})$ \\
\hline H-15 & $1.9(2 \mathrm{H}, \mathrm{m})$ & $1.8(2 \mathrm{H}, \mathrm{m})$ & $1.8(1 \mathrm{H}, \mathrm{m})$ \\
\hline H-16 & $\begin{array}{c}2.84(1 \mathrm{H}, \mathrm{m}) \\
\text { and } 1.9(1 \mathrm{H}, \mathrm{m})\end{array}$ & $\begin{array}{l}1.8(1 \mathrm{H}, \mathrm{m}), \\
1.6(1 \mathrm{H}, \mathrm{m})\end{array}$ & $1.8(1 \mathrm{H}, \mathrm{m}), 1.6(1 \mathrm{H}, \mathrm{m})$ \\
\hline OH-17 & $5.58 \mathrm{~s}$ & ------------------ & ------------------------ \\
\hline H-18 & $0.46(3 \mathrm{H}, \mathrm{s})$ & $0.81(3 \mathrm{H}, \mathrm{s})$ & $0.85(3 \mathrm{H}, \mathrm{s})$ \\
\hline H-19 & $1.32(3 \mathrm{H}, \mathrm{s})$ & $1.36(3 \mathrm{H}, \mathrm{s})$ & $1.41(3 \mathrm{H}, \mathrm{s})$ \\
\hline OH-21 & $4.68(1 \mathrm{H}, \mathrm{t}, \mathrm{J}=6.1)$ & -------------------- & ---------------------- \\
\hline H-21 & $\begin{array}{l}4.39(1 \mathrm{H}, \mathrm{dd}, \mathrm{J}=19,6.1) \\
4.03(1 \mathrm{H}, \mathrm{dd}, \mathrm{J}=19,6.1)\end{array}$ & 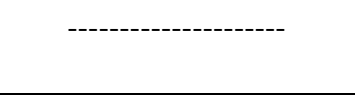 & ----------------------' \\
\hline
\end{tabular}

${ }^{\mathrm{a}}{ }^{1} \mathrm{H}-\mathrm{NMR}$ spectrum recorded in DMSO- $\mathrm{d}_{6}$ by $500 \mathrm{MHz}$ spectrometer.

${ }^{\mathrm{b}}{ }^{1} \mathrm{H}-\mathrm{NMR}$ spectrum recorded in $\mathrm{CDCl}_{3}$ by $500 \mathrm{MHz}$ spectrometer.

${ }^{\mathrm{c}}{ }^{1} \mathrm{H}-\mathrm{NMR}$ spectrum recorded in $\mathrm{CDCl}_{3}$ by $400 \mathrm{MHz}$ spectrometer. 
Table 2: ${ }^{13} \mathrm{C}-\mathrm{NMR}$ assignments of prednisone ${ }^{6}$ and its aerobic HIB biotransformation products $\mathbf{m}_{\mathbf{1}}$ and $\mathbf{m}_{\mathbf{2}}$.

\begin{tabular}{|c|c|c|c|}
\hline $\begin{array}{c}\text { Carbon } \\
\text { No. }\end{array}$ & $\mathbf{1}^{\mathrm{a}}$ & $m_{1}^{b}$ & $m_{2}{ }^{c}$ \\
\hline 1 & $155.6(\mathrm{CH})$ & $34.6\left(\mathrm{CH}_{2}\right)$ & $153.8 \& 155.5(\mathrm{CH})$ \\
\hline 2 & $127.5(\mathrm{CH})$ & $33.7\left(\mathrm{CH}_{2}\right)$ & $128.4 \& 126.8(\mathrm{CH})$ \\
\hline 3 & $185.6(\mathrm{C})$ & $199.7(\mathrm{C})$ & $186.1 \& 186.0(\mathrm{C})$ \\
\hline 4 & $124.3(\mathrm{CH})$ & $124.7(\mathrm{CH})$ & $125.4 \& 123.8(\mathrm{CH})$ \\
\hline 5 & $167.7(\mathrm{C})$ & $168.2(\mathrm{C})$ & $165.8(\mathrm{C})$ \\
\hline 6 & $33.6\left(\mathrm{CH}_{2}\right)$ & $32.0\left(\mathrm{CH}_{2}\right)$ & $31.7 \& 32.0\left(\mathrm{CH}_{2}\right)$ \\
\hline 7 & $32.1\left(\mathrm{CH}_{2}\right)$ & $30.9\left(\mathrm{CH}_{2}\right)$ & $30.5 \& 30.7\left(\mathrm{CH}_{2}\right)$ \\
\hline 8 & $36.1(\mathrm{CH})$ & $36.3(\mathrm{CH})$ & $36.5 \& 37.1(\mathrm{CH})$ \\
\hline 9 & $59.3(\mathrm{CH})$ & $63.2(\mathrm{CH})$ & $60.0 \& 61.2(\mathrm{CH})$ \\
\hline 10 & $42.4(\mathrm{C})$ & $38.3(\mathrm{C})$ & $42.18(\mathrm{C})$ \\
\hline 11 & $210.7(\mathrm{C})$ & $207.7(\mathrm{C})$ & $207.3 \& 207.3(\mathrm{C})$ \\
\hline 12 & $50.3\left(\mathrm{CH}_{2}\right)$ & $50.4\left(\mathrm{CH}_{2}\right)$ & $48.8 \& 50.3\left(\mathrm{CH}_{2}\right)$ \\
\hline 13 & $51.0(\mathrm{C})$ & $49.8(\mathrm{C})$ & $49.9(\mathrm{C})$ \\
\hline 14 & $49.3(\mathrm{CH})$ & $49.7(\mathrm{CH})$ & $48.6 \& 51.2(\mathrm{CH})$ \\
\hline 15 & $23.4\left(\mathrm{CH}_{2}\right)$ & $21.6\left(\mathrm{CH}_{2}\right)$ & $21.6 \& 22.8\left(\mathrm{CH}_{2}\right)$ \\
\hline 16 & $34.1\left(\mathrm{CH}_{2}\right)$ & $36.0\left(\mathrm{CH}_{2}\right)$ & $35.2 \& 35.8\left(\mathrm{CH}_{2}\right)$ \\
\hline 17 & $87.9(\mathrm{C})$ & $217.0(\mathrm{C})$ & $216.3(\mathrm{C})$ \\
\hline 18 & $16.0\left(\mathrm{CH}_{3}\right)$ & $14.7\left(\mathrm{CH}_{3}\right)$ & $13.9 \& 15.3\left(\mathrm{CH}_{3}\right)$ \\
\hline 19 & $19.3\left(\mathrm{CH}_{3}\right)$ & $17.3\left(\mathrm{CH}_{3}\right)$ & $18.2 \& 19.5\left(\mathrm{CH}_{3}\right)$ \\
\hline 20 & $211.9(\mathrm{C})$ & ----- & ---- \\
\hline 21 & $66.6\left(\mathrm{CH}_{2}\right)$ & ----- & ---- \\
\hline
\end{tabular}

${ }^{\text {a }}$ Spectrum recorded in DMSO- $\mathrm{d}_{6}$ by $125 \mathrm{MHz}$ spectrometer.

${ }^{\mathrm{b}}$ Spectrum recorded in $\mathrm{CDCl}_{3}$ by $125 \mathrm{MHz}$ spectrometer.

${ }^{\mathrm{c}}$ Spectrum recorded in $\mathrm{CDCl}_{3}$ by $100 \mathrm{MHz}$ spectrometer. 
$\alpha$-ketol group proton signals at $\delta 4.03$, 4.39 and 4.68 which pointed to its cleavage in addition to the absence of singlet at $\delta 5.58$ assigned for $\mathrm{C}_{17}-\mathrm{OH}$ in $\mathbf{1}$ led us to primarily designate the structure of $\mathbf{m}_{1}$ as androst-4- ene3,11,17-trione.

Further confirmation of the suggested structure of $\mathbf{m}_{\mathbf{1}}$ was achieved by analysis of ${ }^{13} \mathrm{C}-\mathrm{NMR}$ data (Fig. 1a). Table 2 displays a total of 19 carbon signals, two carbons less than the substrate 1. Several DEPT and $\mathrm{HMQC}$ experiments were done to aid the assignment of the different ${ }^{13} \mathrm{C}$-NMR signals to their respective $\mathrm{C}$-atoms. DEPT spectrum at $45^{\circ}$ (Fig. 1b) displayed six carbon signals less than those displayed by ${ }^{13} \mathrm{C}-\mathrm{NMR}$. The missing signals might be attributed to the quaternary carbons number $3,5,10,11,13$, and 17 in the nineteen carbon steroidal skeleton. DEPT spectrum at $90^{\circ}$ (Fig. 1c) showed four signals that are characteristic for the methine carbons $\mathrm{C}_{4}, \mathrm{C}_{8}, \mathrm{C}_{9}$ and $\mathrm{C}_{14}$, while DEPT spectrum at $135^{\circ}$ (Fig. 1d) revealed two methyl groups and seven methylenes in addition to the four signals of the methine carbon atoms (Table 2). The HMQC spectrum (Fig. 2) showed coupling between $\mathrm{C}_{4}$ at $\delta$ 124.75 and $\mathrm{H}-4$ at $\delta 5.669$ while there were no detected couplings between carbons number $3,5,10,11,13$, and 17 at $\delta 199.7,168.2,38.3,207.7,49.8$ and 217 respectively and any protons confirming their quaternary nature.

Structure of metabolite $\mathbf{m}_{1}$ was therefore recognized as, androst-4ene-3,11,17-trione, which corresponds to adrenosterone, a natural hormone secreted from adrenal cortex and has mild androgenic activity ${ }^{7}$.

Fraction $B\left(R_{\mathrm{f}}=0.64\right)$ eluted after fraction A yielded metabolite $\mathbf{m}_{2}$ after suitable purification procedure. An HPLC run using $\mathrm{Rp}-\mathrm{C}_{18}$ column revealed a single peak at $R_{t} 6.8 \mathrm{~min}$. At the same time the sample in hands displayed ${ }^{13} \mathrm{C}$-NMR spectrum with duplicated signals for each carbon atom that indicated the population of a mixture of two closely related components. On the other hand a run on chiral HPLC column, disclosed two peaks with $\mathrm{R}_{\mathrm{t}}=3.4$ and 4.1 minutes in a ratio of $4: 1$ respectively (Fig. 3) most probably indicating that the fraction in hands was a mixture of enantiomers, which was reproducibly obtained after aerobic incubation for $48 \mathrm{~h}$.

The mass spectrum of $\mathbf{m}_{\mathbf{2}}$ revealed a molecular ion peak at $\mathrm{m} / \mathrm{z} 298\left[\mathrm{M}^{+}\right]$ $(100 \%)$ with $60 \mathrm{~m} / \mathrm{z}$ less than $\left[\mathrm{M}^{+}\right]$of 1 suggesting loss of one $\mathrm{m} / \mathrm{z}$ unit in addition to $59 \mathrm{~m} / \mathrm{z}$ of the $\alpha$-ketol group. The ${ }^{1} \mathrm{H}-\mathrm{NMR}$ spectral data (Table 1), demonstrated three downfield olefinic proton signals at $\delta$ $7.59,6.15$ and 6.04 comparable to the values showed by the parent compound $\mathbf{1}$. The doublet centered at $\delta 7.59$ was assigned to $\mathrm{H}-1$, being vicinally coupled to $\mathrm{H}-2$ methine proton doublet at $\delta 6.15$. Vicinal protons with $J$ value of $10.3 \mathrm{~Hz}$ illustrated cis coplanar arrangement. The olefinic proton $\mathrm{H}-2$ appeared as a double doublet centered at 6.15 due to vicinal coupling with $\mathrm{H}-1$ and long 


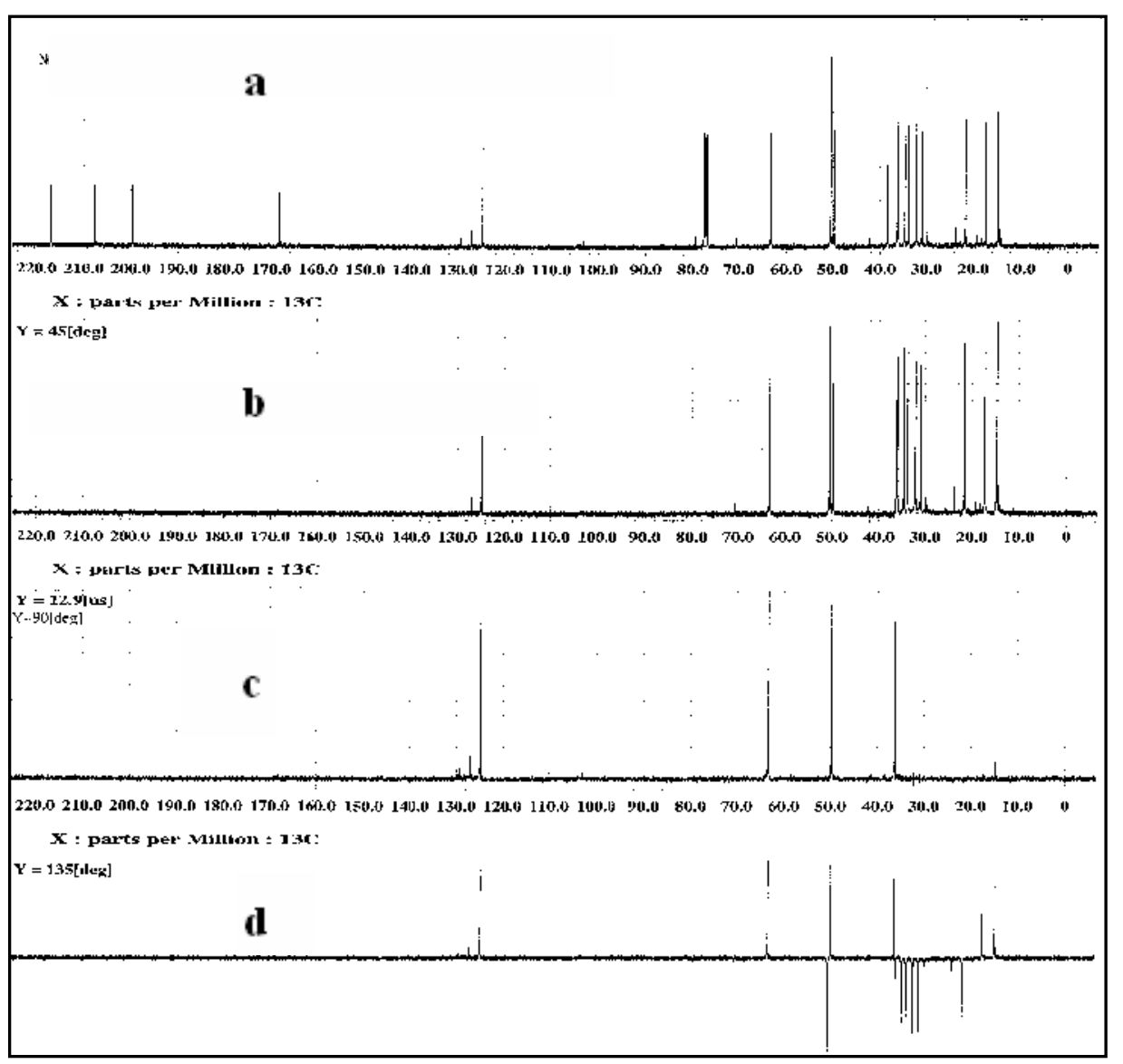

Fig. 1: ${ }^{13} \mathrm{C}-\mathrm{NMR}$ spectrum (a) DEPT spectra at $45^{\circ}$ (b), $90^{\circ}$ (c) and at $135^{\circ}$ (d) of $\mathbf{m}_{1}$. 


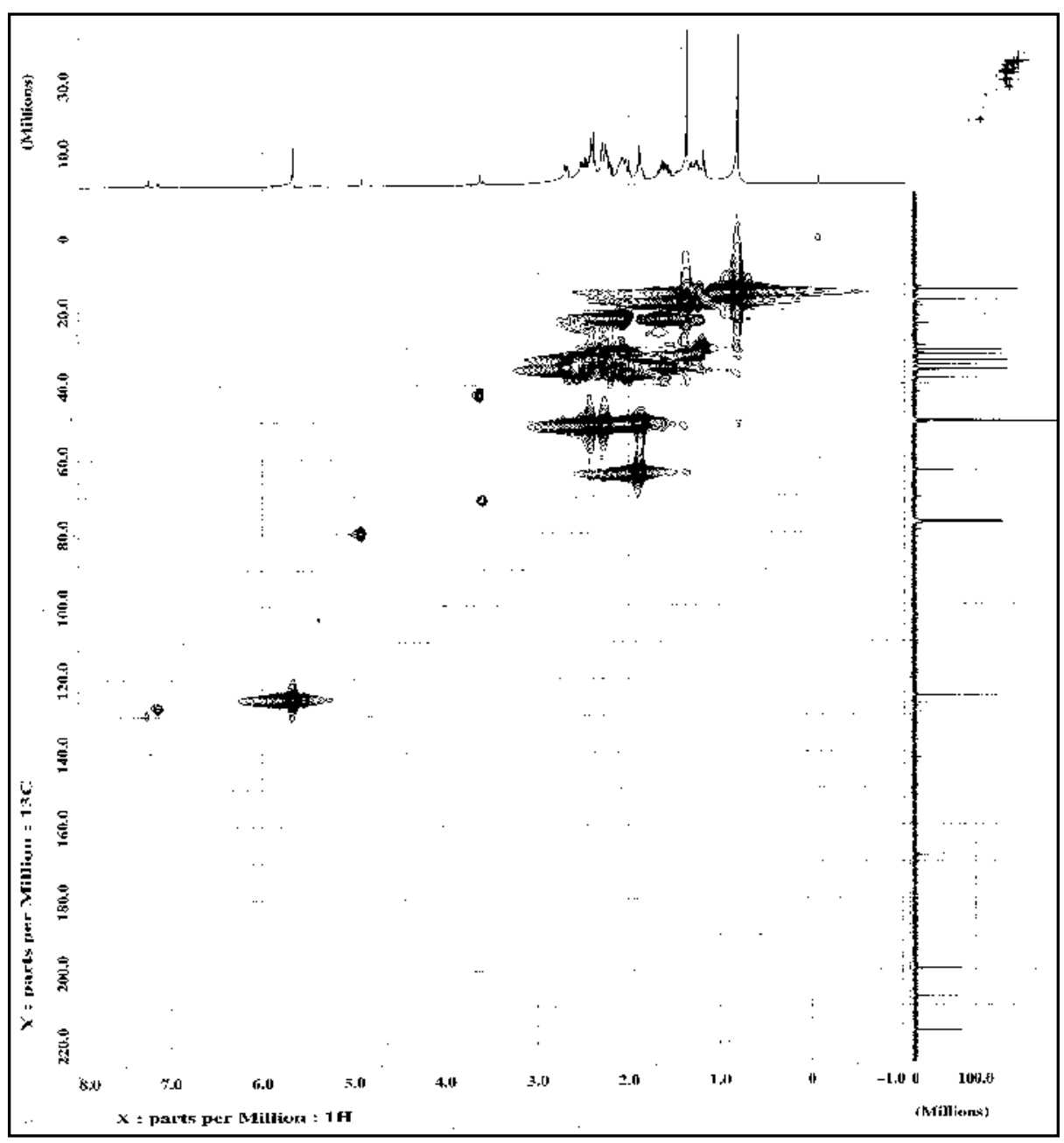

Fig. 2: HMQC spectrum of $\mathbf{m}_{\mathbf{1}}$. 


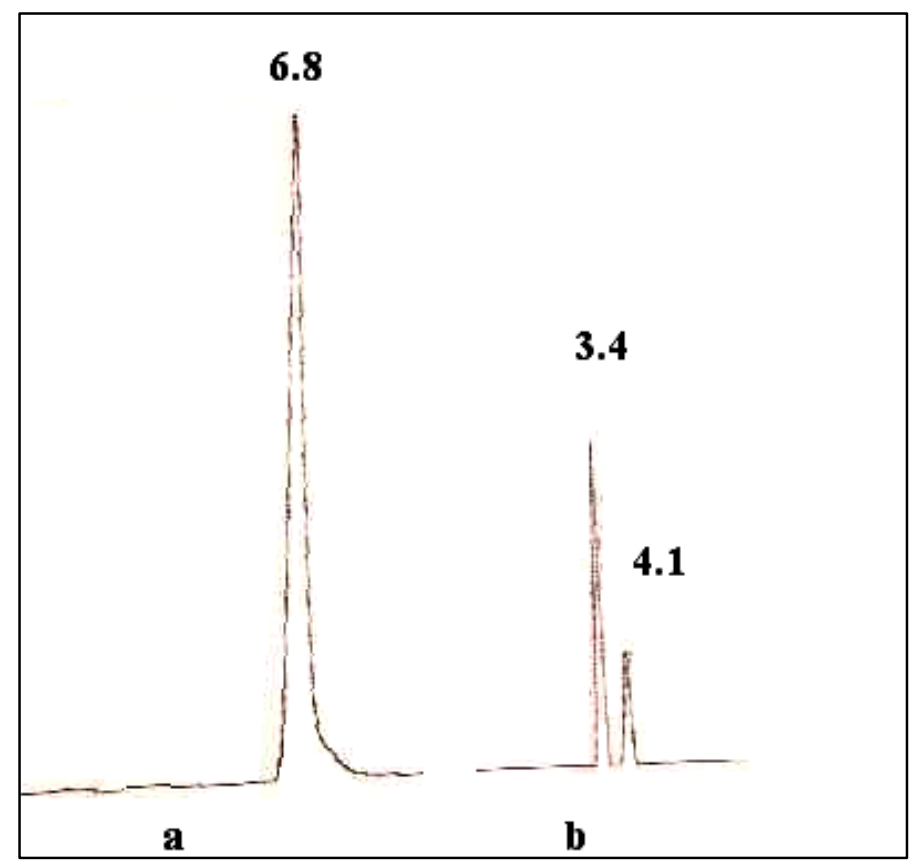

Fig. 3: Analytical HPLC profiles of metabolites $m_{2}$ : (a) Rp C-18 column, $\mathrm{CH}_{3} \mathrm{CN}: \mathrm{H}_{2} \mathrm{O}$ (2:3); (b) chiral column isopropanol: $n$-hexane (1:50).

range " $W$ " coupling $\left({ }^{4} J=1.9\right)$ with $\mathrm{H}-4$ methine proton which appeared at $6.04 \mathrm{ppm}$. Such ${ }^{1} \mathrm{H}-\mathrm{NMR}$ pattern of $\mathbf{m}_{2}$ indicated the preservation of 1,4diene unsaturation like that in prednisone $\mathbf{1}$. As previously observed in the spectrum of metabolite $\mathbf{m}_{\mathbf{1}}$, the absence of the characteristic pattern of $\alpha$-ketol group at $\delta 4.03,4.39$, and $4.68 \mathrm{ppm}$ in addition to the signal corresponding to $\mathrm{C}_{17}-\mathrm{OH}$ at $\delta 5.58$ $\mathrm{ppm}$, led us to propose that the structure of $\mathbf{m}_{2}$ may exist as a mixture of enatiomers of androsta-1,4-diene derivative.

The ${ }^{13} \mathrm{C}$-NMR spectral data, (Table 2), showed signals characteristic of three carbonyl carbons at $\delta 216.33,207.34$ (207.28) and 186.11 (186.01) assigned to $\mathrm{C}_{17}$, $\mathrm{C}_{11}$ and $\mathrm{C}_{3}$ respectively and three olefinic carbons at $\delta 155.51$ (153.86), 128.46 (126.83) and 125.49 (123.89) assigned to $\mathrm{C}_{1}, \quad \mathrm{C}_{2}$ and $\mathrm{C}_{4}$ respectively. The ${ }^{13} \mathrm{C}-\mathrm{NMR}$ chemical shifts of the other $\mathrm{C}$-atoms of the enantiomers $\mathbf{m}_{2}$ are listed in (Table 2). Metabolite $\mathbf{m}_{\mathbf{2}}$ was therefore recognized as mixture of androsta1,4-diene-3,11,17-trione enantiomers.

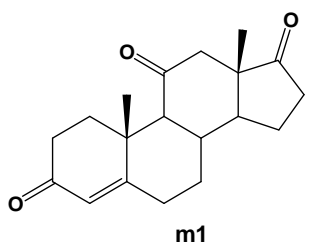


Microbial biotransformation time course study of prednisone 1

The biotransformation of prednisone 1, by HIB mixture under aerobic incubation for $96 \mathrm{~h}$ was monitored by HPLC. A representative HPLC chromatogram, Figure 4, illustrates the retention times of prednisone $\mathbf{1}$ and its metabolites $\mathbf{m}_{\mathbf{1}}$ and $\mathbf{m}_{2}$ after incubation for $48 \mathrm{~h}$. Figure 5 displays the change of the relative concentrations of the three components at $24 \mathrm{~h}$ intervals. It can be observed that after $48 \mathrm{~h}$ incubation, the compounds $\mathbf{1}, \mathbf{m}_{1}$ and $\mathbf{m}_{2}$ showed common reluctant rate pattern of transformation. This may be attributed to gradual depletion of essential environmental elements to maintain the HIB culture vitality leading to its decreased biochemical transformation efficiency.

Matching the patterns of transformation in (Fig. 5), one can observe two phases for accumulation of $\mathbf{m}_{\mathbf{1}}$ and $\mathbf{m}_{\mathbf{2}}$. At the first phase from zero time to $48 \mathrm{~h}$, a steady increase of concentrations took place that apparently occurs at the expense of biotransformation of $\mathbf{1}$. The second phase after $48 \mathrm{~h}$, transformation of prednisone practically remained constant, however, the relative concentration of $\mathbf{m}_{\mathbf{1}}$ increased significantly and relative concentration of $\mathbf{m}_{2}$ decreased approaching zero at the end time of incubation period. Increased $\mathbf{m}_{\mathbf{1}}$ concentration that went in parallel with decreased $\mathbf{m}_{\mathbf{2}}$ concentration may be rationalized by assuming that $\mathbf{m}_{2}$ behaved as substrate for certain strains in HIB mixture having 1 . $\mathrm{NDH}$ (nuclear dehydrogenase) activity that reduced ${ }^{1}$-bond leading to accumulation of $\mathbf{m}_{1}$ on expense of $\mathbf{m}_{2}^{8 \& 9}$. Musharraf et al. isolated the metabolites of adrenosterone $\mathbf{m}_{\mathbf{1}}$ using three different microorganisms ${ }^{6}$. Three metabolites of $\mathbf{m}_{1}$ were identified namely, $\mathbf{m}_{2} ; 17 \beta$ hydroxyandrost-4-ene-3,11-dione $\mathbf{m}_{\mathbf{3}}$, and $17 \beta$-hydroxyandrosta-1,4-diene3,11-dione $\mathbf{m}_{\mathbf{4}}$, (Fig. 6). The formation of $\mathbf{m}_{2}$ from $\mathbf{m}_{1}$ seems to go opposite to our above interpretation ${ }^{6}$ This may be explained in terms of the difference in biocatalyst used in experiments.

The catalytic enzymes involved in aerobic biotransformation of prednisone 1 that yielded the metabolites $\mathbf{m}_{1}$ and $\mathbf{m}_{2}$ can be summarized as: desmolases (17-side chain cleavage), oxidases $(17 \alpha-\mathrm{OH}$ oxidation) and reductases ( 1 . reduction).

Initial anaerobic metabolic investigations of $\mathbf{1}$ by $\mathrm{HIB}$ are in progress in our laboratory.

\section{Acknowledgment}

The project was financially supported in part by the Academy of Scientific Research and Technology of Egypt. 


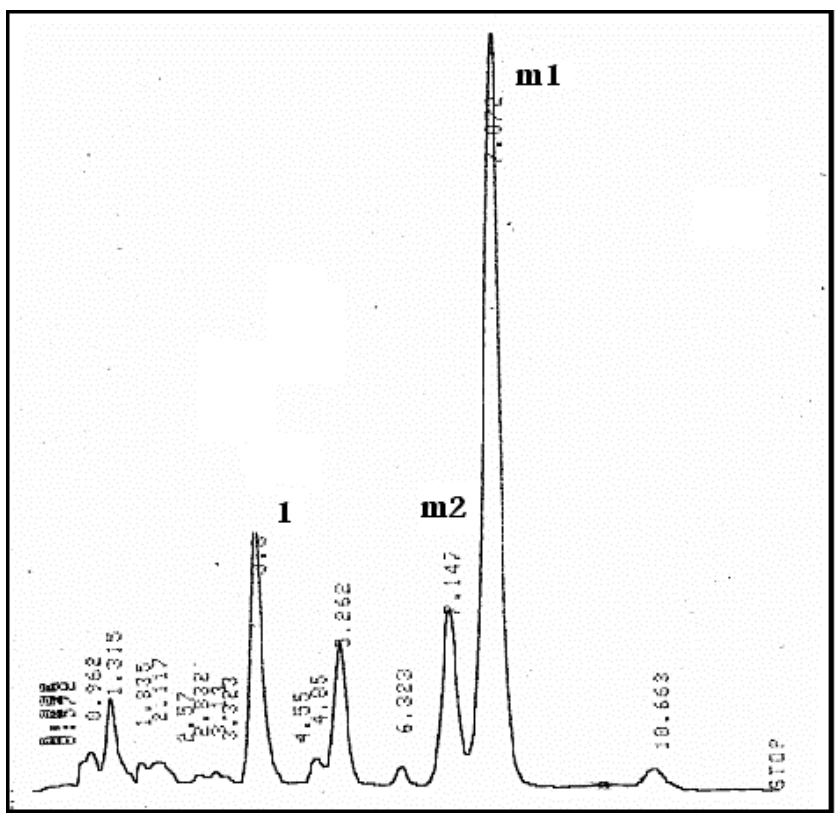

Fig. 4: HPLC chromatogram of the reaction mixture illustrating the relative concentration of $\mathbf{1}$ and its metabolites $\mathbf{m}_{\mathbf{1}}$ and $\mathbf{m}_{\mathbf{2}}$ after $48 \mathrm{~h}$.

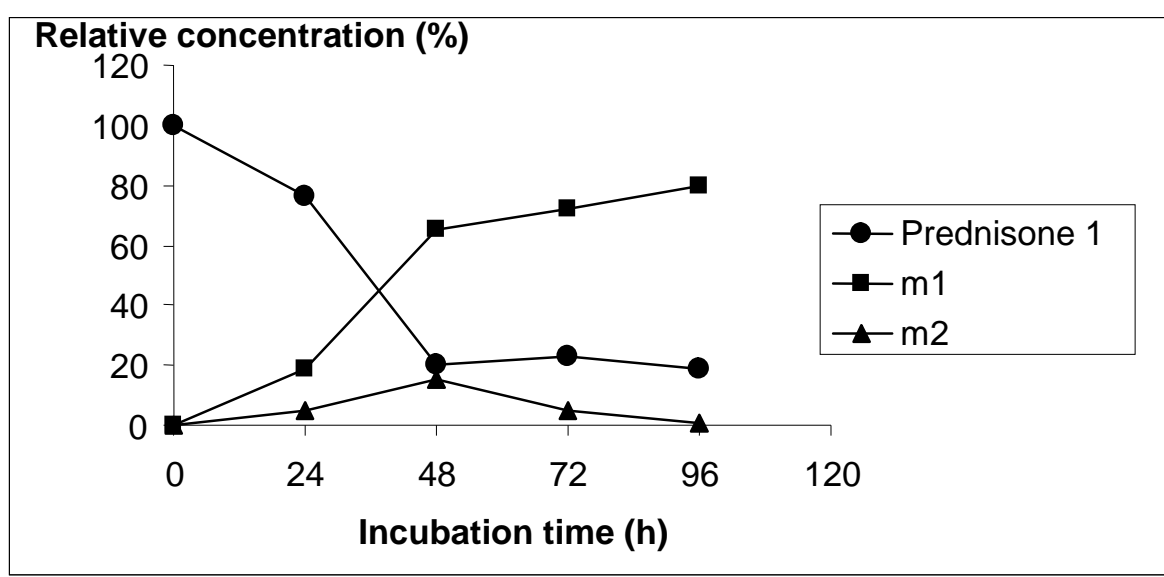

Fig. 5: Time course of biotransformation of prednisone and its metabolites $\mathbf{m}_{1}$ and $\mathbf{m}_{2}$ by HIB under aerobic conditions. 
<smiles>CC12I=[Z]C(=O)C=C1CCC1C2C(=O)CC2(C)C1CC[Te]2(=O)O</smiles>

$\begin{array}{clll}\text { Compound No. } & \text { C1-C2 } & \text { C17 } & \text { Microorganism } \\ \boldsymbol{m}_{1} & ----- & - \text { one } & \\ \boldsymbol{m}_{2} & - \text { ene } & \text {-one } & \text { Cephalosporium aphidicola, Fusarium lini } \\ \boldsymbol{m}_{3} & ----- & \text {-ol } & \text { Cephalosporium aphidicola, Trichothecium roseum } \\ \boldsymbol{m}_{4} & \text {-ene } & \text {-ol } & \text { Cephalosporium aphidicola, Fusarium lini }\end{array}$

Fig. 6: Adrenosterone $m_{1}$ and its metabolites $\mathbf{m}_{2}, \mathbf{m}_{3}, \mathbf{m}_{\mathbf{4}}$ using three different fungal strains ${ }^{9}$.

\section{REFERENCES}

1- K. Kieslich, Arzneimittelforschung, 36, 774 (1986).

2- K. Parfitt; "Martindale", $32^{\text {nd }}$ Edn., USA, Pharmaceutical Press, 1999, pp. 1048-1049.

3- D. D. Miller, R. W. Brueggemeier and J. T. Daiton; "Foye's Principles of Medicinal Chemistry", D. A. Williams, and T. L. Lemke (Editors), $5^{\text {th }}$ Edn., London, Lippincott and Wilkins, 2002, pp. 664-665.

4- M. I. Choudhary, Z. A. Siddiqui, S. G. Musharraf, S. A. Nawaz and Atta-Ur-Rahman, Nat. Prod. Res., 19, 311 (2005).
5- USP Pharmacopoeia XXII. USA, United States Pharmacopoeia Convention Inc, 1999, pp. 1387 1390.

6- S. G. Musharraf, Atta-UrRahman, M. I. Choudhary and S. Sultan Nat. Prod. Res., 16, 345 (2002)

7- I. S. Kleiner, and J. M. Orten, "Biochemistry", $7^{\text {th }}$ Edn., New York: C.V. Mosby Company, 1966, pp. 799-800.

8- V. D. Bokkenheuser, J. B Suzuki, S. T. Polovsky and J. Winter, Appl. Microbiol., 30, 82 (1975)

9- V. D. Bokkenheuser and J. Winter, Am. J. Clin. Nutr., 33, 2502 (1980). 